\title{
Çocukluk Çağı Göz Travmalarının Değerlendirilmesi: Tek Merkezli 5 Yıllık Deneyim
}

\section{Evaluation of Chilhood Ocular Trauma: 5-Year Single-Center Experience}

\author{
Mustafa Eliaçık1, Fırat Erdoğan2, Sevil Karaman1, Göktuğ Demirci1, İlke Özahi Ippek2 \\ ${ }^{1}$ Medipol Üniversitesi Tıp Fakültesi, Göz Hastalıkları Anabilim Dalı, Istanbul, Türkiye \\ 2 Medipol Üniversitesi Tıp Fakültesi, Çocuk Sağlığı ve Hastalıkları Anabilim Dalı, Istanbul, Türkiye
}

\begin{abstract}
ÖZET
Amaç: Çocukluk çağı göz travmalarının epidemiyolojisinin ve prognostik faktörlerinin değerlendirilmesi.

Gereç ve Yöntem: Bu retrospektif çalışmaya, Kasım 2008 ve Kasım 2013 yılları arasında hastanemiz göz kliniğine göz travması ile başvuran 0-16 yaş arasında 248 hastanın, 258 gözü dahil edildi. Hasta dosyaları taranarak yaş, cinsiyet, travmanın tipi ve oluşum yeri, travmanın oluşumundan hastaneye varışa kadar geçen süre, göz içi basınçları, ilk ve son görme keskinlikleri kayıt altına alındı. McNemar ve Ki-kare testi istatistiksel değerlendirilmede kullanıldı.

Bulgular: Çalışmaya dahil edilen 258 gözde erkek/kı oranı 1,3/1 idi. En sık travma uğrama yaşı 7-12 yaș arasında idi. Ön segmentin nonperforan travması $(\% 88,3)$ en sık rastlanılan tip idi. Tedavi sonrasında en iyi düzeltilmiş görmesi 0,5 ve üzerinde olan göz miktarı $\% 70$ ( $n=182$ ) iken 0,05 ve altında kalan göz oranı \%14 (n=36) idi. Takip süresi 1 gün ile 36 ay arasında olduğu tespit edildi. Endoftalmi tespit edilen olgu sayısı $4(\% 1,55)$ iken göz içi yabancı cisim 4 olguda tespit edildi. 6 yaş altında travmaya en sık oyuncaklar neden olur iken 6 yaş sonrasinda en sık etken taş ve sopa gibi cisimler idi. Tüm olguların tanıları, uygulanan tedavileri, oküler komplikasyonları ve tedavi sonuçları rapor edildi.

Sonuç: Çocukluk çağında oküler travmalar nedeniyle ortaya çıkan tek taraflı körlük engellenebilen ve bu konuda bilgilendirme ve eğitimin önemi vurgulanılarak insidansı azaltabilinecek bir problemdir. Böylelikle daha fazla ebeveyn gözlemi, eğitimsel ve yasal düzenlemelerin oluşturulması, bu tip kazaların morbiditesini ve prevalansını azaltılmasında ciddi öneme haizdir. The Journal of Pediatric Research 2014;1(2):70-5

Anahtar Kelimeler: Çocuk, göz travması, epidemiyoloji, görme keskinliği
\end{abstract}

\section{ABSTRACT}

Aim: To assess the epidemiology and prognostic factors of pediatric ocular traumas.

Materials and Methods: This retrospective study included 258 eyes of 248 patients between 0-16 years of age who were presented to ophthalmology clinic of our hospital between November 2008 and November 2013. Age, gender, type and cause of the trauma, time elapsed from the onset of the trauma to admission to the hospital, intraocular pressure, initial and final visual acuities were obtained from the medical records of patients. McNemar and Chi-square tests were used in statistical analyses.

Results: In the 258 eyes included in the study, the male to female ratio was approximately 1.3:1, and most were 7 to 12 years old. Non-perforating trauma in the anterior segment was the most common type of injury ( $88.3 \%$ ). After the treatment, best corrected visual acuity was 0.5 or better in $70 \%$ of the patients, while it was 0.05 or worse in $14 \%$. Follow-up period was ranged from 1 day to 36 months. Endophthalmitis was detected in 4 patients $(1.55 \%)$ and intraocular foreign body was detected in 4 patients. Toys were the most frequent cause of trauma in children under 6 years of age while it was stone and wood in those over 6 years of age. Diagnoses, therapies implemented, ocular complications, and outcomes were reported.

Conclusion: Unilateral blindness in childhood due to ocular traumas is avoidable and its incidence could be markedly reduced by emphasizing an information strategy and education based on prevention of ocular trauma. Thus more adequate adult supervision and educational and legislative measures are necessary and useful in order to reduce prevalence and morbidity of these accidents. The Journal of Pediatric Research 2014; 1(2):70-5

Key Words: Child, eye trauma, epidemiology, visual acuity 


\section{Giriş}

Çocukluk çağında meydana gelen göz travmaları; ambliyopiden sonra kalıcı görme hasarına yol açan en sık ikinci nedendir (1-3). Engellenebilir bir problem olan göz travmaları için tedbir alınması ortaya çıkabilecek sosyal ve maddi yüklerin azaltılabilmesini ve hatta ortadan kaldırılabilmesini sağlayacaktır. Görme miktarında ciddi azalmalara yol açabilecek perforan travmalar hastayı fiziksel ailesini de psikolojik olarak travmatik bir sürece sokmaktadır $(4,5)$. Çocukluk çağı göz travmalarının engellenmesi için travmaya maruz kalan çocukların etiyolojik ve prognozu belirleyen faktörler açısından incelenmesinin, demografik özelliklerinin ortaya konmasının ve uygun tedavi seçeneğinin belirlenmesinin tedavi sonrası görme keskinliğinin miktarı açısından önemli olduğunu düşünmekteyiz. Bu çalışma özellikle izole göz travmalarında acil hekimlerinin hastaya yaklaşımı ve hasta yakınlarının doğru bilgilendirilmesi açısından rehber olması amacıyla yapılmıştır.

\section{Gereç ve Yöntem}

Çalışmanız 2008 Kasım-2013 Kasım tarihleri arasında hastanemiz çocuk acil polikliniğine göz travması ile ilk merkez olarak başvuran ve göz polikliniğine yönlendirilen 248 olgunun 256 gözüne ait dosyaların retrospektif olarak taranması ile elde edilen bilgiler ışığında yapılmıştır. Hastaneye başvurulduğu andan itibaren acil odasında tutulan kayıtlar ve sonrasında göz hekiminin muayenesi sonucunda doldurduğu kartlar taranmak suretiyle yaş, cinsiyet, travmanın oluşundan hastaneye başvurulana kadar geçen zaman aralığı, oluş şekli, oluş yeri, ne ile meydana geldiği, ilk ve en son, en iyi düzeltilmiş görme keskinliği, kapalı göz travmalarında göz içi basınçları, fundus muayeneleri kayıt altına alınmıştır. Hastalar aralarında karşılaştırma yapmak üzere kreş öncesi süt çocuğu (0-2), okul öncesi (3-6), okul çağı (7-12) ve ergenlik dönemi (13-16) yaş gruplarına ayrılmıştır. Istatistiksel değerlendirme SPSS 17.0 ile yapılmış olup, kullanılan testler Ki-Kare ve McNemar testleridir.

\section{Bulgular}

Çalışmamıza dahil olan 248 çocuğun 136'sı erkek 112'si kız idi. Yaş ortalaması $6 \pm 2,1$ yıl (0-16 yıl) olan hastaların \%12'si 0-2 ( $n=30)$ yaş, \%25'i 3-6 ( $n=63)$ yaş, \%40'ı 7-12 $(n=99)$ yaş ve \%23'ü 13-16 ( $n=56)$ yaş grubunda idi (Grafik 1). Travmaya maruz kalan çocuklar cinsiyet olarak incelendiğinde grubun genelinde $(1,3 / 1)$ erkek çocuk üstünlüğü tespit edilmiş iken yaş gruplarına bölünüp incelendiğinde 0-2 yaş ve 3-6 yaş gruplarında cinsiyet farkı olmadığı görülmüştür. Travmaların tamamının ilk başvuru merkezi hastanemiz çocuk acil servisi idi. Travmanın oluşumu ile kurumumuza başvuru arasında geçen süre ortalaması ise 7,6 66,45 saat (1-32 saat) olarak tespit edildi. Travmaları sınıflandırılmasına bakıldığında 218 (\%88) hastanın non-perforan, 30 (\%12) hastada ise perforan travma yaşandığı tespit edilirken, non-perforanların 18'inde $(\% 8,25)$ perforanların ise 6'sında (\%20) ilaveten kapak ve göz etrafı dokularının kontüzyonu var idi. Non-perforan travmalardan $10^{\prime} \mathrm{u}(\% 3,8)$ kimyasal temizlik maddeleri ile bilateral olarak gerçekleşmiş idi. Non-perforan travmaların oluşumunda en başta gelen etken oyuncaklar iken, perforan travmalarda tığ, bıçak gibi kesici aletler ile meydana gelen travmalar birinci sırayı almakta idi (Tablo I). Travmadan etkilenen gözlerin \%56'sı sağ \%44'ü sol göz idi. Travmalar oluş yerlerine göre incelendiğinde non-perforan travmaların çoğunluğu kreş ve oyun parkı (\%40) gibi çocukların oyun amaçlı toplu yaşadıkları yerlerde meydana gelirken, ikinci

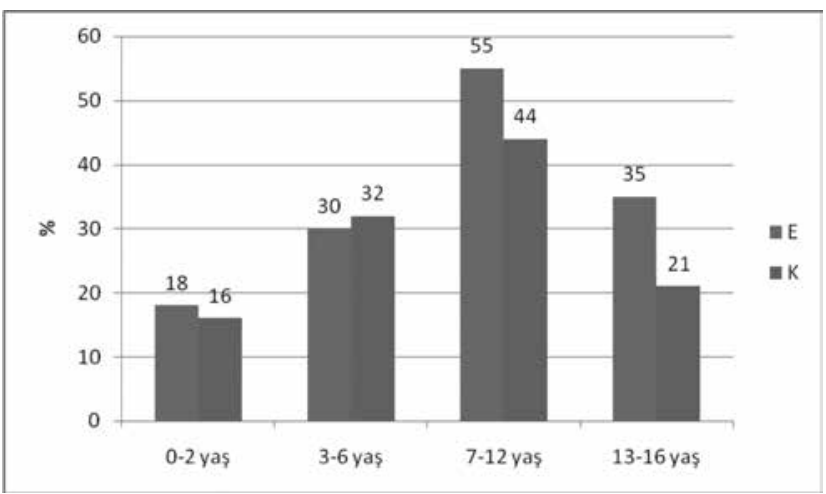

Grafik 1. Izole göz travmalarının yaşa ve cinsiyete göre dağıımı

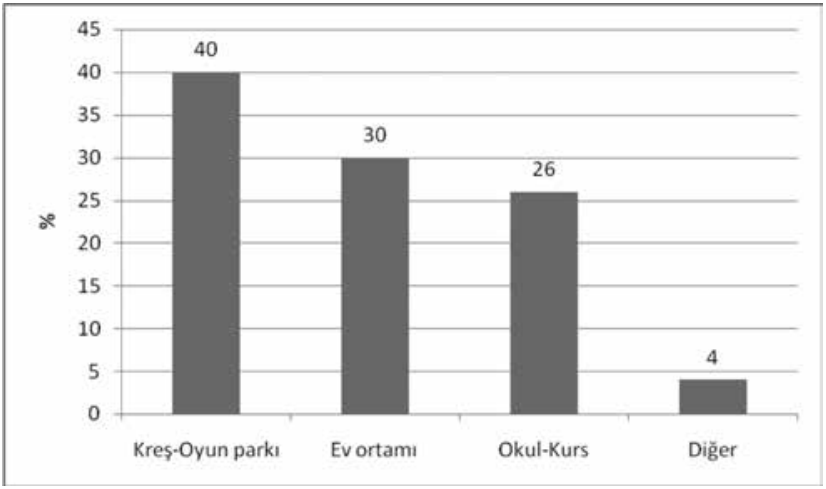

Grafik 2. Izole göz travmalarının oluşum yerine göre dağıımı

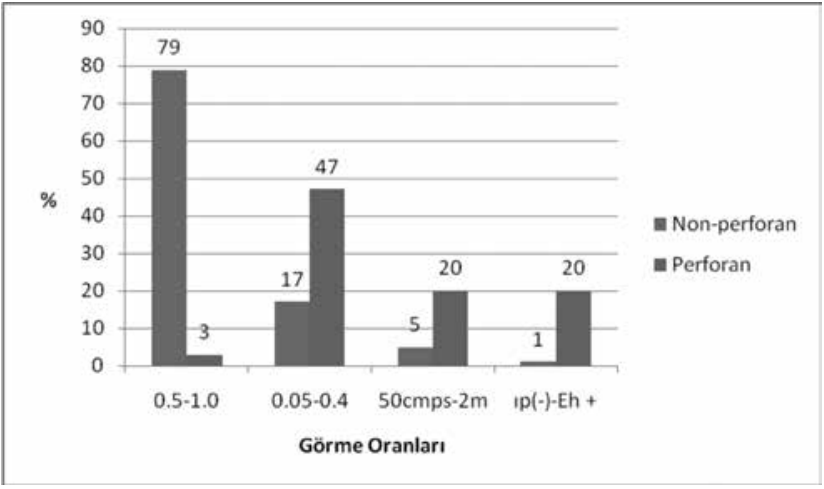

Grafik 3. Izole göz travması sonrası son kontrolde elde edilen görme seviyeleri 
sırada ev ortamı (\%30), üçüncü sırada okul-kurs gibi eğitim kurumları (\%26) almakta idi (Grafik 2). Travmaya maruz kalan çocukların \%87'sinde travma oluşumu esnasında ebeveyn ya da bakımını üstlenen kişinin kontrolü altında olmadığı ve travmaların \%64'ünün ikinci bir çocuk tarafından meydana getirildiği tespit edildi.

Travmaya maruz kalan çocukların aylara göre dağıımı incelendiğinde genel hasta sayısında belirgin bir farklılık gözlemlenmez iken, yaş gruplarına göre yapılan dağılımda okul çağı ve sonrasında travmaların daha çok haziran, temmuz ve ağustos aylarında arttığı görülmüştür. Perforan ve non-perforan travmaların mevsimsel dağılımında sadece perforan travmalarda haziran ayında sayısal olarak bir farklılık var iken istatistiksel açıdan anlamlı fark bulunamamıştır $(p=0,3)$ (Tablo II). Nonperforan travmalarda ylin herhangi bir zamanında belirgin bir farklılaşma göze çarpmamaktadır. Cinsiyet-mevsim analizinde erkek çocuklarda kız çocuklara oranla tüm aylarda istatistiksel olarak anlamlı fark tespit edilmiştir $(p=0,02)$ (Tablo III).

Travmaya uğrayan çocuklardan (kooperasyon yetersizliğine bağlı olarak) görme oranı tespit edilemeyen 32'si tasnif dışı bırakıldığında, kalan çocuklar görmelerinde meydana gelen azalmaya bağlı olarak hafif (5/10-10/10), orta (5/100-4/10) ve ağır (elli santim-iki metreden parmak sayma) ve çok ağır (ışık persepsiyonu (-) ile el hareketi) olmak üzere dört kategoriye

\begin{tabular}{|c|c|c|c|}
\hline \multirow[b]{2}{*}{ Travma nedeni } & \multicolumn{3}{|c|}{ Olgu Sayısı (\%) } \\
\hline & Erkek & KIz & Toplam \\
\hline Oyuncak & $56(\% 41)$ & $47(\% 42)$ & $103(\% 41)$ \\
\hline Künt & $42(\% 31)$ & $36(\% 32)$ & $78(\% 31,5)$ \\
\hline $\begin{array}{l}\text { Kırtasiye Malzemesi } \\
\text { (kalem, kağıt vb.) }\end{array}$ & $12(\% 9)$ & $10(\% 9)$ & $22(\% 8,9)$ \\
\hline Metal & $7(\% 5)$ & $5(\% 4,5)$ & $12(\% 4,8)$ \\
\hline Odun-Cam & $6(\% 4,5)$ & $3(\% 2,7)$ & $9(\% 3,6)$ \\
\hline Kesici delici alet & $4(\% 3)$ & $3(\% 2,7)$ & $7(\% 2,8)$ \\
\hline $\begin{array}{l}\text { Kimyasal (temizlik } \\
\text { maddeleri) }\end{array}$ & $2(\% 1,5)$ & $4(\% 3,5)$ & $6(\% 2,4)$ \\
\hline Trafik Kazası & $1(\% 0,7)$ & 0 & $1(\% 0,4)$ \\
\hline Fişek, maytap & $1(\% 0,7)$ & 0 & $1(\% 0,4)$ \\
\hline Havyan & $2(\% 1,5)$ & $2(\% 1,8)$ & $4(\% 1,6)$ \\
\hline Diğer & $3(\% 2,2)$ & $2(\% 1,8)$ & $5(\% 2)$ \\
\hline Toplam & $136(\% 100)$ & $112(\% 100)$ & $248(\% 100)$ \\
\hline
\end{tabular}

ayrıldı. Bunların tedavi öncesi ve tedavi sonrası üçüncü ayda görme oranları okul öncesi 3 yaş üstü çocuklarda "E eşeli" ile okul çağı ve sonrası çocuklarda Snellen eşeli kullanılarak kayıt altına alınmıştır. Travma sonrasında ilk muayenede tespit edilen görme oranlarının travma tipine göre dağııımı Tablo IV'de gösterilmektedir. Tedavi sonrasında nonperforan travmaya maruz kalmış çocukların \% 79'unda hafif derecede görme hasarı mevcut iken bu oran perforan travmaya maruz kalmış çocuklarda \%3 seviyesinde kalmıştır. Perforan ve nonperforan travmalar neticesinde tedavi sonrası görme keskinliklerinin dağılımını Grafik 3'de görülmektedir.

Non-perforan ve perforan travmalarda hasar gören bölgelerin dağılımı Tablo V'de gösterilmektedir. Tüm travmalar incelendiğinde kornea $(\% 56,5)$ en sık hasar alan doku olarak karşımıza çıkmaktadır.

Sauer ve ark.'nın yapmış olduğu bir çalışmada çocukluk döneminde göz içi basınç değerlerinin yaş ile uyumlu olarak değiştiği ifade edilse de ortalama göz içi basınç normal değerleri çalışmalarında $10-20 \mathrm{mmHg}$ olarak belirtilmiştir (6). Çalışmamızda da $20 \mathrm{mmHg}$ göz içi basınç değeri üst sınır kabul edilmek suretiyle bu değeri aşan ve $20-25$ mmHg göz içi basıncına sahip 66 olgunun değerlerinin normale dönmesi için gereken süre $36,2 \pm 8,3$ saat olarak tespit edildi. Göz içi basınç değerleri 25 mmHg'nin üzerinde olan ve antiglokomatöz tedaviye intiyaç duyan 24 olgudan 20'sinin göz içi basınç değerleri 48 saat içerisinde $20 \mathrm{mmH}$ 'nin altına düşürüldü. Topikal ve/veya oral antiglokomatöz tedaviye rağmen göz içi basıncı ortalama $28,7 \pm 2,5 \mathrm{mmHg}(26-32 \mathrm{mmHg})$ olan 4 olgunun ön kamarada hifema temizliği yapılmak suretiyle göz içi basınç değerleri normalin altına düşürülmüştür.

Geçirilen oküler travma sonrasında sekonder enfeksiyonlara bağlı oluşan endoftalmiler incelendiğinde ilk 12 saat içerisinde başvuran olgular içerisinde yer alan perforan bir travma olgusunda $(\% 0,38)$ endoftalmi gözlenir iken 12 saat sonrasında yapılan başvurular incelendiğinde bu sayının tüm seride dört $(\% 1,55)$ olduğu tespit edildi. Endoftalmilerin tamamı perforan travma olgularında tespit edilirken üç olguda göz içinde yabancı cisim mevcut idi. Hastaların tedavi kuruluşlarına başvuru süreleri ile endoftalmi gelişme olasılığı arasında pozitif korelasyon saptanmıştır $(r=0,450, p=0,01)$.

Göz kliniğinde yapılan muayenenin ardından non-perforan travmaya maruz kalan 216 olgudan korneal abrazyona bağlı epitelyum defekti ve seidel negatif lamellar korneal kesiye sahip olgularda hasta tercihleri doğrultusunda antibiyotikli

Tablo II. Travmaların yıllara ve mevsimlere göre dağılımı

\begin{tabular}{|l|l|l|l|l|l|l|l|}
\hline & $\mathbf{2 0 0 8}$ & $\mathbf{2 0 0 9}$ & $\mathbf{2 0 1 0}$ & $\mathbf{2 0 1 1}$ & $\mathbf{2 0 1 2}$ & $\mathbf{2 0 1 3}$ & Toplam \\
\hline Ocak-Mart & 0 & 12 & 10 & 13 & 13 & 15 & 63 \\
\hline Nisan-Haziran & 0 & 14 & 13 & 12 & 11 & 16 & 66 \\
\hline Temmuz-Eylül & 0 & 11 & 13 & 14 & 15 & 12 & 65 \\
\hline Ekim-Aralık & 10 & 10 & 9 & 11 & 13 & 11 & 64 \\
\hline Toplam & 10 & 47 & 45 & 50 & 52 & 54 & 258 \\
\hline
\end{tabular}


pomad ile sıkı bandaj ya da saat başı topikal damla tedavisi ile bandaj kontakt lens uygulaması yapılmıştır (Resim 1). Göz kapağı (14), konjonktiva (10), kornea (22) dokularında laserasyonları olan 32 hastanın primer sütürasyonları, pupil mesafesini örtecek ya da göz içi basıncında antiglokomatöz tedaviye direnç gösterecek yükselmeler meydana gelen 4 olgunun ön kamara temizliği, 16 olguda tespit edilen kornea yüzeyindeki yabancı cisimlerin uzaklaştırılması ve takip süresi boyunca ortaya çıkan 6 travmatik kataraktın fakoemülsifikasyon ve göz içi mercek implantasyonu ameliyatları hastanemiz göz kliniğinde gerçekleştirilmiştir. Göz içi yabancı cisim tespit edilen 4 hasta (2 cam, 2 metal çapağı) ile perforasyon sonrası arka segment patolojisi (3 intraoküle hemoraji, 1 retina dekolmanı) kliniğimizde vitreoretinal cerrahi ekipmanı ve deneyimli göz cerrahı olmadığından başka bir merkezlere sevk edilmiştir (Resim 2). Korneal sütürler ortalama $10,72 \pm 1,07$ ay (9-12 ay) içerisinde alınmıştır. Korneal sütürasyon neticesinde ambliyopi gelişen $16(\% 6,2)$ olgunun kapama tedavisi on yaşlarından gün alınana kadar devam etmektedir. Tüm müdahalelere rağmen olguların hepsinde yüz güldürücü sonuç almak mümkün olamamış olguların 6'sında (\%2,3) absolü göz meydana gelmiştir (Resim 3).

\section{Tartışma}

Izole göz travmaları dünya genelinde çocukluk çağında görülen görme azalmalarının en başta gelen nedenidir $(2,5)$. Okul öncesi döneminde çocukların motor becerilerinin yetersizliği, okul çağı ve ergenlik döneminde ise merak, bilgisizlik ve risk analizinin olmayışı gibi nedenler onların bu tip travmalara maruz kalmalarına neden olmaktadır $(4,5)$. Gelişmiş ülkelerde travma neticesinde ortaya çıkan görme azalmalarının tedavisi ve görmenin geri kazanılmasını sağlayacak rehabilitasyon dönemi için önemli miktarda

Tablo III. Travma mevsim ve cinsiyete göre dağıımı

\begin{tabular}{|l|l|l|l|}
\hline & Erkek & Kız & Toplam \\
\hline Ocak-Mart & 34 & 29 & 63 \\
\hline Nisan-Haziran & 35 & 31 & 66 \\
\hline Temmuz-Eylül & 38 & 27 & 65 \\
\hline Ekim-Aralık & 35 & 29 & 64 \\
\hline Toplam & 142 & 116 & 258 \\
\hline
\end{tabular}

Tablo IV. Illk muayenede elde edilen görme derecelerinin travma tiplerine gore dağııımı

\begin{tabular}{|c|c|c|c|}
\hline & Nonperforan & Perforan & Toplam \\
\hline & n (\%) & n (\%) & n (\%) \\
\hline$\geq 0,5$ & $94 \% 42$ & $0 \% 0$ & $94 \% 36$ \\
\hline $0,05-0,5$ & $62 \% 27$, & $5 \% 17$ & 67 \%26 \\
\hline $2 \mathrm{mps}-0,05$ & $32 \% 14$ & $11 \% 36$ & $43 \% 17$ \\
\hline IP (-)-50 cmps & $16 \% 7$ & $6 \% 20$ & $22 \% 9$ \\
\hline Vizyon alınamayan & $24 \% 10$ & $8 \% 27$ & $32 \% 12$ \\
\hline Toplam & $228 \% 100$ & $30 \% 100$ & $258 \% 100$ \\
\hline
\end{tabular}

fon, sağlık bütçesinden ayrılmaktadır (2). Gelişmekte olan ülkelerde ise yaşamsal sağlık sorunlarının çokluğu nedeniyle travma mağduru hastaların aynı ilgiyi görmesi oldukça zor görünmektedir. Bu sebeple, izole göz travmaları nedeniyle hasta ve yakınlarının karşılaşacağı fiziksel ve psikolojik zorlukları azaltmanın bir yolu da travmaların etiyolojilerinin inceleyip, gerekli önlemleri alacak olan sağlık hizmetlerinin geliştirilmesidir.

Çalışmamızın öncelikli amacı olarak Kasım 2008Kasım 2013 tarihleri arasında hastanemizin çocuk acil ve göz polikliniğine başvurmuş izole göz travmalı hastaların dosyalarından elde edilen bilgiler ışığında, bölgemizde gelişen göz travmalarının anatomisini çıkartmaktır. Bu sayede prognozu etkileyen belli başlı faktörlerin çalışmamızda hedef olarak tespit edilen en son düzeltilmiş görme üzerine olan etkilerini incelenmiştir. Çalışmamızın ikincil amacı ise her zaman bir göz hekimi ile çalışma şansı bulamayan acil servis hekimlerinin travmaya yaklaşımını standardize etmek, hasta ve hasta yakınlarının aydınlatılmasını sağlayacak bir bilgi rehberi oluşturmaktır.

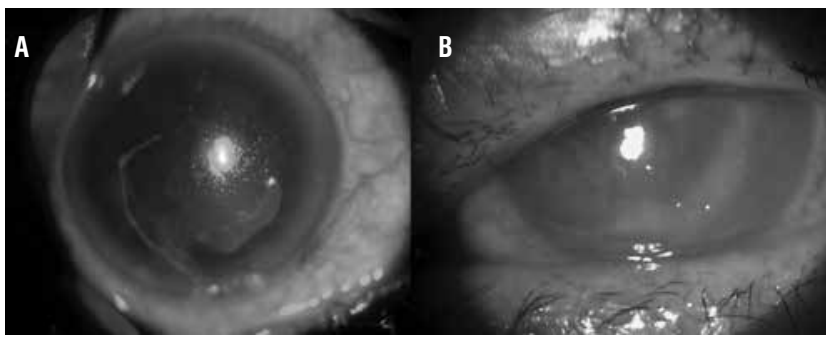

Resim 1. A) Boncuk tabancasına bağlı korneal abrazyon, B) Kağıt kesiğine bağlı lamellar korneal hasar ve sekonder gelişen enfeksiyon

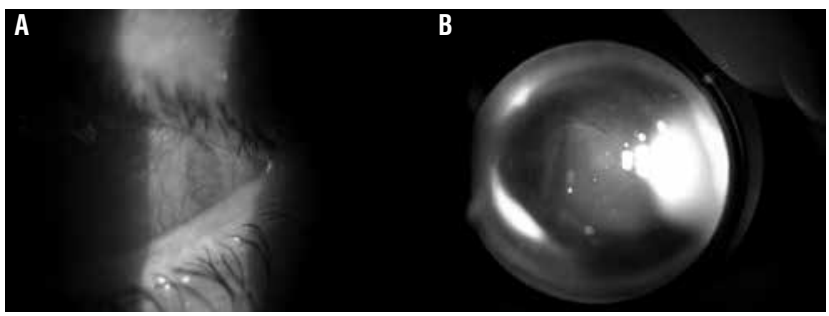

Resim 2. A) Non perforan travmada konjonktiva kesisi, B) Non-perforan travmada gelişen at nalı yırtıklı retina dekolmanı

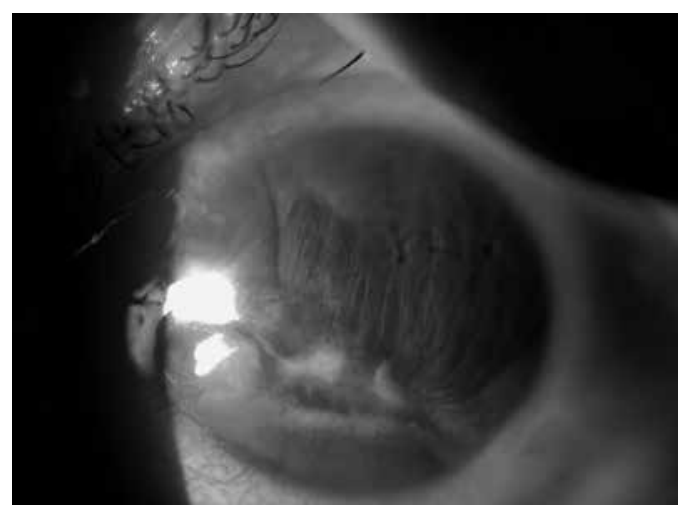

Resim 3. Travma sonrası postoperatif 24. ay lp(-) göz 
Tablo V. Travma tiplerine göre hasar gören göz dokularının dağılımı

\begin{tabular}{|l|l|l|}
\hline & Non-Perforan & \multicolumn{1}{|c|}{ Perforan } \\
\cline { 2 - 3 } & $\mathbf{n}(\%)$ & $\mathbf{n}(\%)$ \\
\hline Kornea & $124 \% 54,3$ & $22 \% 73,3$ \\
\cline { 1 - 1 } Sklera & $42 \% 18,2$ & $8 \% 26,7$ \\
\cline { 1 - 1 } Konjonktiva & $35 \% 15,4$ & $14 \% 46,6$ \\
\cline { 1 - 1 } Kapak-Kantus & $18 \% 7,9$ & $6 \% 20$ \\
\hline
\end{tabular}

Mevcut literatürde yer alan bilgiler toplumun sosyal yaşantısında ve alışkanlıklarındaki değişimler neticesinde güncelliğini yitirdiği için, travmanın ortaya çıkış nedenlerinin, oluşum yerlerinin ve sekellerinin oldukça farklılıklar gösterdiği gözlemlenmiştir.

Çocukluk çağında meydana gelen göz yaralanmalarında erkek/kız oranı literatürdeki çalışmalarda 2:1 ile 6:1 arasında değişmektedir (7-15). Diğer bazı çalışmalarda ise çocukluk çağında cinsler arası bir farklılık gösterilememiştir $(16,17)$. Bizim çalışmamızda ise çalışma grubunun genelinde erkek kız oranı 1,3/1 idi. Yaş dağılımı ve cinsiyet farkı incelendiğinde özellikle okul öncesi yaş gurubunda iki cins arasında farklılığa rastlanılmaz iken okul çağı ve ergenlik döneminde de erkek/ kız oranı 1,5/1 olarak tespit edildi. Bu farkın kapanmasındaki en önemli unsurun günümüzde okullarda artan şiddet olayları olduğu düşünülmektedir. Okul sınırları içinde ya da dışında bir öğrencinin diğerine uyguladığı tehdit, zorbalık ve şiddet günümüzde hızla artmaktadır. Bunun sorumlusu olarak toplumda da huzursuzluk oluşturan suç oranlarındaki artış gösterilmektedir. Milli Eğitim Bakanlığı son yıllarda, şimdiye kadar göz ardı edilen silah, bıçak ve benzeri kesici delici suç aletleri ile diğer öğrencilere ve eğitim kadrosuna verilen zararları medya kanalı ile toplumla paylaşarak bu önemli soruna dikkat çekmeye çalışmaktadır (18).

Çocukluk çağında meydana gelen non-perforan göz travmalarının etiyolojisinde ev ortamı ve oyun alanları başı çektiğini gösteren birçok çalışma mevcuttur $(10,12,14,16,19,20)$. Sarı ve ark.'nın yapmış olduğu çalışmada özellikle okul öncesi yaş grubunda meydana gelen nonperforan göz travmalarının en sık ev ortamı $(\% 58,7)$ oluştuğunun altını çizmiş bunun en önemli sebebinin de ilgisiz ve eğitimsiz aileler olduğunu ifade etmişlerdir (19). Küsbeci ve ark.'nın yapmış olduğu bir diğer çalışmada ise toplumun yaşam tarzında meydana gelen değişimler neticesinde nonperforan travmaların daha çok kreş ve oyun evlerinde $(\% 49,1)$ görüldüğü belirtilmektedir (20). Bizim çalışmamızda travmanın meydana geldiği yer olarak oyun evleri ve kreşler (\%42) öne çıkarken ev ortamında (\%30) meydana gelen travmalar da azımsanmayacak kadar fazladır. Özellikle oyun parklarında yaşanan göz travmaları mağdurlarının çoğunlukla bir başka çocuk tarafından şiddete maruz kalmaları neticesinde yaşanmaktadır. Mevcut kreş ve anaokulların kabul ettiği çocuk sayısı ile doğru orantıda personel bulundurmamaları, ev ortamında ise çocuğun bakımını üstlenen kişiler tarafından daha sıkı kontrol altına alınmaları travmanın meydana geldiği alanların son yıllarda değişmesine neden olmuştur.
Mowatt ve ark.'nın yapmış olduğu ve non-perforan travmaların yı içerisindeki dağılımını inceleyen çalışmada mart ve mayıs aylarında sıklığın arttığı, en az ise şubat ayında olduğu tespit edilmiştir (21). Ilhan ve ark.'nın yapmış olduğu bir başka çalışmada ise pediatrik yaş grubunda meydana gelen oküler travmalara sonbahar aylarında daha sık rastlanıldığı ifade edilmiştir (22). Çalışmamızda travma sayısı ile mevsimler arasında belirgin birliktelik tespit etmedik. Bu durumun metropol yaşam şeklinin etkisi ile çocukların oyun alanlarının sokaklardan daha çok ev ve kapalı alanlara kayması olduğunu düşünmekteyiz. Bunun aksine perforan travmalardaki erkek üstünlüğü ve travmanın meydana geldiği yer açısından başta açık oyun alanları ve sokakların göze çarpması literatürdeki diğer kaynaklar ile uyum göstermektedir $(12-15,21,22)$.

Göz travması sonrası prognozu belirleyen en önemli unsurlardan birinin ilk muayenede tespit edilen görme miktarı olduğu daha önce yapılan çalışmalarda belirtilmiştir (2325). Travma oluşumu esnasında optik sistemi oluşturan ön segment (kornea, iris, lens) ve arka segment (retina, vitreus, optik sinir) yapılarından hangisinin ne kadar hasar gördüğü görme keskinliğinin düzeyini etkileyen en önemli faktörlerdendir. Literatürde en sık etkilenen dokunun kornea (\%45-\%53) olduğu ifade edilirken bizim çalışmamızda da bu yönde bulgulara ulaşılmıştır. Korneanın anatomik olarak gözün nen önünde yer alması nedeniyle kolayca hasara uğrayabilmesi ve aldığı hasar (nonperforan veya perforan) miktarı bizim çalışmamızda belirleyici faktörlerden olmuştur. Dürük ve ark.'nın yaptığı çalışmada travma sonucu kornea hasra görme oranı \%59 olarak bildirilirken ilk görme keskinliğinin düşük olmasının prognoz daha kötü olmasına neden olduğu da ifade edilmiştir (26). Kargı ve ark.'nın yaptığı çalışmada görme miktarı 0,1'in üzerinde olan hastaların tamamının tedavi sonunda tespit edilen görme miktarının daha yüksek olduğu hatta \%53'ünde 0,5 üzerinde bir görme keskinliğine sahip olduğu saptanmıştır (14). Bizim çalışmamızda ilk muayenede görme keskinliği 0,5 ve üzerinde tespit edilen 164 (\%63) gözün ilk müdahale ve sonrasında yapılan ambliyopi tedavileri ile 86'sı (\%33) 0,5 ve üzerinde görmeye sahip olduğu tespit edilmiştir.

Oküler travmalar sonrası ortayan çıkan endoftalmiler prognozu etkileyen bir diğer önemli faktördür. Tedavi sürecinde; hastaneye başvuru süresinin uzaması, travma neticesinde bütünlüğünü yitirmiş göz küresi dokusu üzerinde gelişen ikincil enfeksiyonlar endoftalmilerin ortaya çıkmasında önemli rol oynamaktadır. Göz içinde yabancı cisim olmaksızın meydana gelen travmalarda endoftalmi görülme sıklığı \%2,4-\%7,4 iken bu oran eğer travmaya bir de göz içi yabancı cisim eşlik ediyor ise \%4,7-\%11,3 seviyelerine yükselmektedir (23). Gün ve ark.'nın yaptığı ve dokuz yıllık pediatrik endoftalmi vakalarının retrospektif olarak incelendiği çalışmada göz kliniğine endoftalmi ile sevk edilen 14 olgunun 12'sinde (\%85) olayın başında bir oküler travma öyküsü olduğu ifade edilmiştir. Aynı çalışmada bu olguların sadece 5 'inde görme miktarının 0,1'den fazla olduğu, 9'unda pthizisbulbi geliştiği görülmüştür (27). Gül ve ark.'nın yaptığı çalışmada hastaneye başvuru süresi ile endoftalmi gelişimi 
arası da pozitif korelasyon olduğu ifade edilmiştir. Yine bu çalışmanın sonuç bölümünde ilk 12 saat içerisinde başvuran olgularda endoftalmi gelişim sıklı̆̆ \%1,35 iken bu sürenin 24 saat üzerine çıkması ile oran \%7 tespit edilmiştir (28). Literatürde oküler travma sonrası sağlık merkezine başvuru yapılanan kadar geçen süre için ortalama $16,5 \pm 8,5$ saat (1-72) iken bizim çalışmamızda 7,6 $\pm 6,45$ saat (1-32 saat) olarak tespit edilmiştir $(12,14,16,19-25)$. Başvuru süresindeki kısalık nedeniyle çalışmamızda endoftalmi sayısı sadece $4(\% 1,55)$ olgu ile sınırlı kalmıştır.

Çalışmamızın daha önce yapılan çalışmalara göre en önemli farkı; retrospektif olarak incelenen beş yıllık süre boyunca travmaya uğramış tüm hastalara ilk başvurularından hastanede gördükleri tedavi ve sonrasındaki takipleri müddetince tek merkez ve aynı göz hekimi tarafından izlenilmiş olmalarıdır. Bu sayede tutulan kayıtların standardizasyonu sağlanarak elde edilen bilgilerin güvenirliliği arttırımıştır.

Tüm bu bilgilerin ışığında özellikle kreş ve anaokulu gibi çok sayıda çocuğun sınırlı gözetim altında yaşadığı alanlarda alınabilecek önlemler, okul öncesi yaş gurubu çocuklarda izole göz travmalarını azaltmasının yanında, travmalar neticesinde meydana gelebilecek kalıcı görme azalmalarının hem çocuk hem de ailelerinin ömür boyu yüzleşmesini gerektirecek maddi ve manevi yüklerden kurtaracaktır. Bunun yanında yazının hazırlanması esnasında literatürde taranan ulusal makalelerde travma geçirmiş hastalar için standart bir sınıflandırma sisteminin bulunmaması sağlık kuruluşları arasındaki iletişimi sekteye uğratacak ve hastanın yanlış değerlendirilmesi ile sonuçlanarak tedavinin başarılı olmamasına neden olabileceğinden bir oküler travma sınıflamasının oluşturulması çok önemlidir.

Çıkar Çatışması: Yazarlar bu makale ile ilgili olarak herhangi bir çıkar çatışması bildirmemiştir.

\section{Kaynaklar}

1. Nelson LB, Wilson TW, Jeffers JB. Eye injuries in childhood: demography,etiology, and prevention. Pediatrics 1989; 84: 438-41.

2. Kaur A, Agrawal A. Paediatric ocular trauma. Current Science 2005; 89: 43-6.

3. Strahlman E, Elman M, Daub E, Baker S. Causes of pediatric eye injuries. A population-based study. Arch Ophthalmol 1990; 108: 603-6.

4. MacEwen CJ, Baines PS, Desai P. Eye injuries in children: the current Picture. Br J Ophthalmol 1999; 83: 933-6.

5. Scribano PV, Nance M, Reilly P, Sing RF, Selbst SM. Pediatric nonpowder firearm injuries: outcomes in an urban pediatric setting. Pediatrics 1997; 100: E5.

6. Sauer A, Abry F, Blavin J, Saleh M, Gaucher D, Meyer N, Bourcier T, Speeg-Schatz C. Sedated intraocular pressure and corneal thickness standards in children from birth to 10 years of age. J Fr Ophtalmol 2011; 34: 238-42.

7. Kaslıoğlu Ş, HAvbekiroğlu A, Tamsel Ş, Tümşen D, Ziylan Ş, Akmut T. Epidemiologic evaluation of eye traumas. Turk $J$ Ophthalmol 2001; 31: 484-91.
8. Çakırer S, Güzey M, Dikici K, Tolun H. Epidemiologic evaluation of eye traumas. T KlinOftalmoloji 1994; 4: 13-6.

9. Koval R, Teller J, Belkin M, Romem M, Yanko L, Savir H. The Israeli Ocular Injuries Study. A nationwide collaborative study. Arch Ophthalmol 1988; 106: 776-80.

10. Çetin EN, Saraç G, Kaşıkçı A, Avunduk AM, Yaylalı V, Yıldırım C. Cocukluk çağı açık göz yaralanmalarının epidemiyolojik ve klinik özellikleri. Turk J Ophthalmol 2012; 42: 16-99.

11. Cariello AJ, Moraes NS, Mitne S, Oita CS, Fontes BM, Melo LA Jr. Epidemiological findings of ocular trauma in childhood. Arq Bras Oftalmol 2007; 70: 271-5.

12. Gökyiğit B, Akar S, Öztürk A, Yılmaz ÖF Çocukluk çağı izole göz travmaları. T Oft Gaz 2005; 35: 155-62.

13. Ben Zina Z, Jamel F, Wissam K, Rym K, Mustapha A, Mohamed A, Mohamed C. [Ocular trauma in children: report of 136 cases]. Tunis Med 2000; 78: 580-3.

14. Kargı SH, Hoşal B, Saygı S, Gürsel E. Epidemiologic evaluation of eye traumas. MN Oftalmoloji 1998; 5: 385-9.

15. Aritürk N, Sahin M, Oge I, Erkan D, Süllü Y. The evaluation of ocular trauma in childrenbetween ages 0-12. TurkJPediatr 1999; 41: 43-52.

16. Lithander J, Al Kindi H, Tönjum AM. Loss of visual acuity due to eye injuries among 6292 school children in the Sultanate of Oman. Acta Ophthalmol Scand 1999; 77: 697-9.

17. Yıldırım C, Yaylalı V, Kıldacı B, Özden S. Açık göz yaralanmalarının epidemiyolojik özelliklerinin incelenmesi. MN Oftalmoloji 1998; 5: 390-5.

18. Kepenekci YK, Cinkir S. Bullying among Turkish high school students. Child Abuse Negl 2006; 30: 193-204.

19. Sarı A, Adıgüzel U, Dinç E, Argın A, Yılmaz A, Öz Ö, Yıldııım Ö. Çocukluk Çağı Delici Göz Yaralanmalarının Epidemiyolojik Değerlendirilmesi. T Oft Gaz 2008; 38: 504-9.

20. Küsbeci T, Yiğit T, Demirhan E, Çatal Ç, Tezcan S. Çocukluk Çağı Göz Travmalarının Epidemiyolojik Değerlendirilmesi. Kocatepe Tıp Dergisi 2012; 13: 153-9.

21. Mowatt L, McDonald A, Ferron-Boothe D. Paediatric ocular trauma admissions to the University Hospital of the West Indies 2000-2005. West Indian Med J 2012; 61: 598-604.

22. Ilhan $H D$, Bilgin $A B$, Cetinkaya $A$, Unal $M$, Yucel I. Epidemiological and clinical features of paediatric open globe injuries in Southwestern Turkey. Int J Ophthalmol 2013; 6: 855-60.

23. Kaynak S. Travma Sonrası Endoftalmiler Ve Tedavisi. Ret-Vit 2003; 11: 218-27.

24. Özdemir M, Durmuş Ç, Çinal A. Çocukluk çağı perforan göz travmalarında prognostik faktörler. MN Oftalmoloji 2002; 9: 301-4.

25. Öncel N,Kadıyoran N, Çetinkaya Y, Önder F. Çocukluk çağı perforan göz yaralanmalarında görsel prognozu etkileyen faktörler. T Oft Gaz 2003; 33: 297-304.

26. Dürük K, Budak K, Turaçlı E, Işıkçelik Y, Çekiç O. Delici göz yaralanması (497 olgunun sonuçları). T Oft Gaz 1993; 23: 299303.

27. Gün FA, Özdek Ş, Gürelik G Reisoğlu B. Pediatrik Endoftalmi Olgularında Dokuz Yıllık Takip Sonuçlarımız. Ret-Vit 2011; 19: 171-4.

28. Gül A, Yaşar T, Çağlar Ç, Esmer O. Endophthalmitis rate after open-globe injuries in the area of the city of Van. Turk $J$ Ophthalmol 2010; 40: 359-62. 